\title{
THE RESURGENCE OF OLD FORMS IN THE EXPLOITATION OF NATURAL RESOURCES: THE COLONIAL ONTOLOGY OF THE PRIOR CONSULTATION PRINCIPLE ${ }^{1}$
}

Douglas de Castro

\begin{abstract}
Post-Doc in International Economic Law - São Paulo Law School (FGV). PhD in Political Science - University of São Paulo (FFLCH-USP). Master's in law - University of São Paulo (FD-USP). LL.M. in International Law - J. Reuben Clark Law School (BYU). Visiting Scholar in the Foundation for Law and International Affairs (Washington D.C.). Researcher in the Global Law Center - São Paulo Law School (FGV). Attorney in the Cerqueira Leite Advogados (CLA).
\end{abstract} E-mail: douggcastro@gmail.com

\begin{abstract}
The need to deal with anthropogenic effects over the environment surfaced in the 1960s mainly due to accidents all over the world with severe impacts on the environment. Therefore, International Environmental Law gained traction and international institutions legitimacy based on the universality of the formation of International Law and the objectivity and neutrality of the science, generating essential exclusions and implication for Global South countries. As colonial domination as part of the imperial projects ceased with the recognition of the sovereignty and self-determination of nations, a new form of granting access to natural resources was necessary. The study relies on TWAIL and Elite Theory as the theoretical framework to unveils the role of International Law and local elites to legitimize the domination and exclusion. To that effect, we hypothesize that International Law and Institutions are proxies of the old ways of imperialism and colonial venture by imposing legal obligations and standard practices to countries disregarding their own experiences, cultures, and values. As part of the methodological strategy, we adopt the case study of the Prior Consultation Principle as the most representative stance of our argument, seeking the confirmation of the embedded colonial tenets. Also, we use the content analysis in direct and indirect sources as the research technique, which is conducted with the help of the computer-assisted qualitative data analysis software (CADQAS) called ATLAS.ti.
\end{abstract}

Keywords: International Environmental Law; Prior Consultation Principle; Imperialism; TWAil; Elite Theory.

1 A version of this paper has been presented at the International Conference on Policy Diffusion and Development Cooperation, May 16-19, 2018, Federal University of São Paulo, Brazil. 


\section{O RESSURGIMENTO DE FORMAS ANTIGAS DE EXPLORAÇÃO DOS RECURSOS NATURAIS: A ONTOLOGIA COLONIAL DO PRINCÍPIO DA CONSULTA PRÉVIA}

\section{RESUMO}

A necessidade de lidar com os efeitos antrópicos sobre o meio ambiente surgiu na década de 1960, principalmente devido a acidentes em todo o mundo, com impactos severos sobre o meio ambiente. Portanto, o Direito Internacional do Meio Ambiente ganhou força e legitimidade com base na universalidade da formação do Direito Internacional e na objetividade e neutralidade da ciência, assim, gerando exclusões e implicações essenciais para os países do Sul Global. Considerando que a dominação colonial como parte dos projetos imperiais cessou com o reconhecimento da soberania e autodeterminação das nações, uma nova forma de acesso aos recursos naturais era necessária. Este estudo tem como quadro teórico o Third World Approaches to International Law (TWAIL) e Teoria das Elites, cujo papel é desvendar o papel do Direito Internacional e das elites locais para legitimar a dominação e a exclusão. Nesse sentido, nossa hipótese é a de que o Direito Internacional e as Instituições são proxies dos antigos modos de imperialismo e colonialismo, impondo obrigações legais e práticas padronizadas a países, desconsiderando as suas próprias experiências, culturas e valores. Como parte da estratégia metodológica, adotamos o estudo de caso do Princípio da Consulta Prévia como a postura mais representativa do nosso argumento, buscando a confirmação da ontologia colonial a ele incorporada. Além disso, utilizamos a análise de conteúdo em fontes diretas e indiretas como técnica de pesquisa, que é realizada com o auxílio do software de análise de dados qualitativos assistido por computador (CADQAS) chamado ATLAS.ti.

Palavras-chave: Direito Ambiental Internacional; Princípio da Consulta Prévia; Imperialismo; TWAIL; Teoria das Elites. 


\section{INTRODUCTION}

"Universal law is for lackeys. Context is for kings". (Gabriel Lorca, Discovery Commander ${ }^{2}$ )

In Star Trek we find a representative picture of the imperialistic logic of the existing body of International Law nowadays: the relation "us" (Federation of planets) against "them" (Klingons); the expansionist project in the phrase "boldly going beyond the final frontier"; and the use of the universal meanings for exclusionary purposes as stated in the above Gabriel Lorca's utterance.

According to Eslava, Obregón, and Ureña in ANGHIE (2016), the imperialistic venture has dimensions:

1. The so-called strict, a historical framework that takes into account the colonial project of the great European empires beyond their territorial limits in search of additional resources for capital accumulation (starting point) and the waves of decolonization in the Global South leading to the formal recognition of the self-determination principle by International Law; and

2. The broad, a dimension associated with a more sophisticated and subtle form of imperial domination thru metanarratives that permeates international institutions and law, which are embraced by local elites in the formation of the political and legal institutions as part of a modern project of development.

As such, the process of building and developing international institutions in the post-colonial era is an empirical representation of the broad dimension of imperialism. It is an intentional political process that justifies the continuation of the colonial expansion under the old mission civilisatrice. Constitutes the ideological struggle that permeates the international system since Westphalia based on the universality of values and truth that the natural law imposes to everyone. Thus, justifying thru the law [...] la producción de dispositivos que ponen em situación de inferioridad y subordinación lo descubierto, para asi colonizarlo y explorarlo [...] (SIERRA-CAMARGO, 2017, p. 170).

2 From the TV Show Star Trek: Discovery. For more see http://www.imdb.com/title/ tt5171438/?ref_=ttqt_qt_tt. Access: Feb, 10, 2018. 
According to Wallerstein (2007), the appeal to universalism as a form of metanarrative takes three types: (1) the policies pursued by the leaders of the pan-European world based on human rights and democracy; (2) that there is a civilizational clash in the world; and (3) the only option available for developing countries is to embrace and accept the market economy and neoliberalism tenets.As such, this political process assumes a moralistic, intimidating and arrogant tone that imposes the pseudo-ideology to guarantee the realization of the national interest of the developing countries.

As an intentional political process, international institutions are saturated with the forms of universalism to ensure scientific and rational grounds, thus, legitimizing it as a modern condition that leaves behind old traditions (WALLERSTEIN, 2007; ESCOBAR, 2011; SANTOS, 2018). In this process, International Law plays an important role, which, according to JHW Verzijl, quoted in Anghie (2006, p.739):

\begin{abstract}
Now there is one truth that is not open to denial or even to doubt, namely that the actual body of international law, as it stands today, not only is the product of the conscious activity of the European mind, but also has drawn its vital essence from a common source of beliefs, and in both of these aspects it is mainly of Western European origin.
\end{abstract}

In this sense, it is possible to observe the convergence of the imperial and colonial projects in the formation of the principles of International Environmental Law. The capture and exploration of natural resources have always played an essential role in European expansion as a form of capital accumulation. The use of nature as the space and object of exploration needs a legitimizing device to sustain it, which encounters in International Environmental Law the mechanisms to provide the rationale for the increment of mining, monocultures, and large hydropower projects on a "sustainable" basis. As presented by Alimonda (2011, page 22):

I want to begin by highlighting the point that I am interested in developing at this moment: the persistent coloniality that affects Latin American nature. The same, as well as biophysical reality (its flora, its fauna, its human inhabitants, the biodiversity of its ecosystems) and its territorial configuration (the sociocultural dynamics that articulate these ecosystems and landscapes significantly) appears before global hegemonic thinking and before the dominant elites of the region as a subaltern space, 
which can be exploited, destroyed, reconfigured according to the needs of the current accumulation regimes.

One of the mechanisms that we find in International Environmental Law is the prior consultation principle. This principle is widely recognized and used on both international and domestic law as a form of inclusiveness and emancipation of people affected by the use of natural resources. It is a form of reconciliation between the social and economic development with the damages to the environment (both considered inevitable) by allowing the participation in the decision-making process of the local population. Principle 19 of the Rio Declaration (1992) states:

States shall provide, in a timely manner, to potentially affected States, prior notification and relevant information on activities which may have a significant negative impact on the environment and which shall be consulted as soon as practicable and in good faith. ${ }^{3}$

Upon these initial considerations, the central argument of this paper is to point out that the prior consultation as described in Principle 19 of the Rio Declaration is merely a formality to legitimize the exclusion of indigenous peoples, small farmers, among other minorities that depend on the nature for survival. In other words, the international and local legal orders reproduce the broad dimension of imperialism by excluding minorities from providing their perceptions of the impacts of large projects and placing them in the position of "against the development." As such, the prior consultation principle becomes an instrument for the domination of the local communities, which is into the debate as a formality that does not ensure their hearing vis-à-vis the "benefits" advocated by the majority.

The paper promotes de analysis of the argument using as the theoretical framework the Third World Approaches to International Law (TWAIL), which will help to shed light on the use of prior consultation principal, thus, pointing out the ambivalence between its language of alleged emancipatory/participatory character and the practice experienced by the communities affected by the development projects. Additionally, in the

3 In www.onu.org.br/rio20/img/2012/01/rio92.pdf.

4 For example, Article 15 of Convention 160 of the International Labor Organization prescribes that: The rights of the peoples concerned to the natural resources existing on their lands should be specially protected. These rights cover the right of such peoples to participate in the use, management and conservation of the resources mentioned. 
local dimension, the paper uses the Elite Theory to explain how local elites embrace international institutions with the promise of economic and social development that does not reach the people outside of the elite strata.

The Brazilian case provides the empirical dimension for our argument. In the last couple of years, we have been observing an increasing of large infrastructure projects and environmental accidents that expose the weakness of the prior consultation principle and the vulnerability of the local population, especially indigenous people. For that matter, we have selected two representative cases to test the argument: the Belo Monte Dam construction and the accident in the Fundão Basin.

\title{
1 TWAIL AND ELITE THEORY - LOOKING TO THE PRIOR CONSULTATION PRINCIPLE THRU THE LENS OF THE DECO- LONIZATION THINKING
}

\subsection{Imperialism and symbolic violence}

Before presenting TWAIL and Elite Theory as the theoretical framework for this study, it is necessary to discuss the background condition for their existence and importance: imperialism. As stated by Young (2016, p. 16):

\begin{abstract}
The term 'empire' has been widely used for many centuries without, however, necessarily signifying 'imperialism'. Here a basic difference emerges between an empire that was bureaucratically controlled by a government from the centre, and which was developed for ideological as well as financial reasons, a structure that can be called imperialism, and an empire that was developed for settlement by individual communities or for commercial purposes by a trading company, a structure that can be called colonial
\end{abstract}

As such, the concept of imperialism is grounded on the exercise of power [...] either through direct conquest or (latterly) through political and economic influence that effectively amounts to a similar form of domination: both involve the practice of power through facilitating institutions and ideologies (YOUNG, 2016, p. 27). ${ }^{5}$

5 Interesting to note that even gender discourse is used as a tool for imperial domination depending on the context and interests at stake: Positing the nation as Imperial Mother can be viewed, on the one hand, as a reworking of France's imperial identity, but also as the expression of concerns relating to the future of the French race, sexual morals, and the position of France in the colonized territories. The feminized version of imperial identity functioned to some degree not only as an assertion of plenitude toward the colonized, but also as a symbol of the hope of a national regeneration abroad (FISCHERTINÉ; GEHRMANN, 2008). 
The critical point in this discussion involves performing actions towards spreading institutions and ideologies that propagate social and political structures as a form of domination and discrimination for imperial purposes; thus, a sort of violence itself. ${ }^{6}$ The economic dimension is an essential part of the imperialistic project (see for instance what Payer (1074) calls "the debt trap"); however, not to the point of a merely colonial venture, but one larger in scope and purpose that demands a high level of bureaucratic control to dictates the rules and conditions for participation in the political arena. ${ }^{7}$

The controlling aspect conducing to domination is the violence that Zizek (2008) is concerned. The commitment of crimes and terrorist acts, civil unrest, and international conflicts constitute a type of abuse that is perceived as upfront and perpetrated by somewhat identified agents, thus, not an unnoticed phenomenon. According to Zizek (2008), we should also take a step back to understand in what context these outbursts of violence happen to identify the hidden dimension of the violence that sustains the efforts to fight the perceived violence and promote tolerance (as such, a paradox).

The hidden aspects of violence are called symbolic, in which ontology presents the subjective and objective dimensions. The subjective side of violence is the one that brings undesired perturbation to the normal functioning of the state-of-affairs or status quo of the institutions. The objective violence is the one imposed unilaterally to define and set the parameters of the normal or smooth functioning of the institutions, which manifest itself in a specific form of language and actions towards domination or imposing a predefined universal meaning.

Going further to the analysis of the forms that violence might assume, it is reasonable to say that the possession of the material conditions is only one spectrum of the goal to make international institutions to operate in the normal mode. There is the additional need to build this

6 No one engaged in thought about history and politics can remain unaware of the enormous role violence has always played in human affairs, and it is at first glance rather surprising that violence has been singled out so seldom for special consideration. In On Violence. 1 ed. New York: Harcourt Brace Javanovich, 1970, p.6.

7 The speech made by Lord Cruzon at the Byculla Claub in 1905 is representative if this logic: To fight for the right, to abhor the imperfect, the unjust or the mean, to swerve neither to the right hand nor to the left, to care nothing for flattery or applause or odium or abuse it is so easy to have any of them in India never to let your enthusiasm be soured or your courage grow dim, but to remember that the Almighty has placed your hand on the greatest of his ploughs, in whose furrow the nations of the future are germinating and taking shape, to drive the blade a little. In https://archive.org/stream/lordcurzonsfarew00curzrich/lordcurzonsfarew00curzrich_djvu.txt. Last Access: July 10, 2017. See also: A. SIVANANDAN. New circuits of imperialism. Race \& Class, v. 30, n. 4, p. 1-19, 1 abr. 1989. 
state of affairs by propagating a universal set of meanings so powerful that becomes an ideology, thus, shaping the social reality and worldviews within the boundaries of the dominant group (Eagleton, 2007). ${ }^{8}$

Therefore, contesting the model presented by institutions or offering an alternative view of the reality is a perturbation of what is considered normal by the international community or by the countries that consider themselves the rightful representatives of universal moral values. This narrative is what Chimni (2006, p.15) refers to:

There is the old idea, which has withstood the passage of time, that dominant social forces in society maintain their domination not through the use of force but through having their worldview accepted as natural by those over whom domination is exercised. Force is only used when absolutely necessary, either to subdue a challenge or to demoralize those social forces aspiring to question the "natural" order of things.

\title{
1.2 The legitimation of violence and TWAIL
}

Regarding providing the basis for rationale and legitimation for the logic of domination, the intentional language of the International Law is instrumental (KOSKENNIEMI, 2006). ${ }^{9}$ The perception of the narrative of International Law is shared by Mutua and Anghie (2000, p.31):

\begin{abstract}
The regime of international law is illegitimate. It is a predatory system that legitimizes, reproduces and sustains the plunder and subordination of the Third World by the West. Neither universality nor its promise of global order and stability make international law a just, equitable, and legitimate code of global governance for the Third World. The construction and universalization of international law were essential to the imperial expansion that subordinated non-European peoples and societies to European conquest and domination. Historically, the Third World has generally viewed international law as a regime and discourse of domination and subordination, not resistance and liberation.
\end{abstract}

As such, this dialectic view of International Law is called Third

\footnotetext{
8 This is what Habermas calls forms of technocratic management. See Habermas, J. (1991). The Structural Transformation of the Public Sphere: An Inquiry into a Category of Bourgeois Society (Sixth Printing edition). Cambridge, Mass: The MIT Press.

9 This study sets the limitation to International Institutions and Law as devices for domination, however, the techniques might include technology as well. See HEADRICK, D. R. The Tools of Empire: Technology and European Imperialism in the Nineteenth Century. 1 edition ed. New York: Oxford University Press, 1981.
} 
World Approaches to International Law (TWAIL), which relies of Critical Theory to deconstruct the tenets of International Law, not to destroy it but to unfold the its essence in order to discover real intentions in the construction of the world legal order and present an alternative based on values and social aspects of non-European countries. With that in mind, TWAIL is subject to an intense debate to identify it as a theory or/and a methodology or even just a praxis of resistance against the imperial logic of using the law as a form of legitimizing the use of symbolic violence (OKAFOR, 2008; GRUBER, 2000). To Mattei (2013, p. 268) in his book Plunder-When the Rule of Law is Illegal, the process of construction of this logic is based on the following method:

\footnotetext{
The rhetorical artifice used in the process of curbing deviant behavior and claiming, as universal and inevitable, the Western modalities of social organization and economic development centered on individualism and social fragmentation, is usually an explicitly juridical concept: "international human rights." In the interests of these rights, a doctrine of "limited sovereignty" has threatened the traditional nature of international law as a decentralized system based on territoriality and has advocated the need for decentralization to make it more like any other West national legal system. (Translated freely by the Author).
}

For starters, the common discourse within International Institutions and regimes is that International Law possesses the attribute of being universal, meaning that has no temporal or physical constraints. However, this mega discourse or metanarrative covers the premises of the formation of International Law: (1) Europe is the center; (2) Christianity is the basis for civilization; (3) Capitalism is innate to humans, and the only form of dealing with the economy; and (4) Imperialism is a necessity to save the "savages" from themselves (BEDJAOUI, 1979). The metanarrative of the universality of International Law based on such grounds is violence to alternative views of the world that are valid on their right (LYOTARD, 2004).

As stated in the introduction of this study, for Anghie (2016) imperialism possess two dimensions, which in both aspects the concept of sovereignty is essential. In the historical dimension, the lack of legal personality of the non-sovereign states reassures the legal position of the European countries, which is reinforced by Positivist stance: 
The colonial confrontation was not a confrontation between two sovereign states, but between a sovereign European state and a non-European state that, according to the positivist jurisprudence of the time, was lacking in sovereignty. Such a confrontation poses no conceptual difficulties for the positivist jurist who basically resolves the issue by arguing that the sovereign state can do as it wishes with regard to the nonsovereign entity, which lacks the legal personality to assert any legal opposition (ANGHIE, 1999, P.3).

Regarding the imperial dimension related to the domination thru subtle devices, the principle of sovereignty kept playing a vital role in the construction of the world legal order after the II World War. For the Great Powers that emerged winners from the World War, the need to build a new international law to restore peace, security and cooperation was premised in (1) the recognition that non-European powers possess the right to self-determination, which was a direct repudiation to colonization; and (2) states were to be governed by human rights.

Although the formation of the United Nations as the guardian of peace and security in the World might be considered a noble enterprise, the reality is that the hegemony of the world affairs was transferred from Europe to the emerging powers that allotted permanent seats in the UN Security Council, namely the United States, Britain France, the Soviet Union, and China. With that, the hegemony over world affairs was secured, however, the Positivist stance that first ensured the legitimacy of domination and self-preservation of the European Powers wouldn't work in an international system based on equal sovereign states and the primacy of respecting human rights (MEARSHEIMER, 2014). In the economic arena, the Third World countries were targeted by the Bretton Woods institutions: The World Bank, the International Monetary Fund (IMF), the General Agreement on Tariffs and Trade (GATT), and the rapid expansion of transnational corporations.

Therefore, the old forms of advancing towards new territories and resources were substituted by the international institutions and law; however, how to deal with the local resistance and specificities to implement this universal project? The role of the elites during the decolonization process in different historical periods and regions were instrumental to undermine the opposition and accommodate the need for a development project based on values and principles exogenous to local communities, so they might reach the modernity era by abandoning traditional and outdated practices and values. There was no place for such competing worldviews in modernity, so elite was encumbered to lead the way. 


\subsection{Elites in the incorporation of universal tenets}

The concept of elites is based on the notion that in every society in the course of history there is a minority group that rules by controlling and disputing the most critical power resources. As such, the existing strings of elite theory relies on explaining elite behavior, interaction, transformation, and the connection of these instances to state outcomes. Thus, regime type and change, liberalization, states, and many other political phenomena are the scopes of elite theory (HOLLANDA, 2011).

Elite Theory is rooted in the classical sociology, especially in the works of Max Webber, Gaetano Mosca, Vilfredo Pareto, and Robert Michels, among others that contributed immensely to the development of a theoretical field with ontological and epistemological independency and intersection with other theories as rational choice, and political culture for instance and other fields of study as law and international relations (PUTNAM, 1976).

Considering that the concept of elites might be applied to all aspects of the social organization (political, economic, media, academic, and so forth), for this study, we shall restrict our analysis to political elites as the one directly involved in the formation of law. Best et al. (2017. p. 3) state that political elites are [...] individuals and small, relatively cohesive, and stable groups with disproportionate power to affect national and supranational political outcomes on a continuing basis. ${ }^{10}$

The exercise of power by the elites is related to capacity, personality, skills, material conditions, intellectual and moral superiority, and networks. One might say that these attributes of power can be summarized into material and symbolic resources. The capacity of the mobilization of material resources by elites seems to be close to the Marxist notion of the ruling class, which is based on the possession of the means of production. However, it is important to note that the idea of elite power is not rooted in the economic aspect as the elite is considered a small group rather than a

10 For a comprehensive study and inventory of ontological and epistemological dimensions of the Elite Theory we suggest: BEST, H. et al. (EDS.). The Palgrave Handbook of Political Elites. 1st ed. 2018 edition ed. London, United Kingdom: Palgrave Macmillan, 2017. 
social class (REIS; MOORE, 2005). Regarding symbolic power, Jean-Pascal Daloz in Best et al. (2017. p. 507) clarifies the mechanism of acquiring and sustaining such power in the following terms:

In contemporary democratic settings, however, the issue of the symbolic superiority of top-level political actors is framed in somewhat different terms. Even though they still have to stand out and above, political elites also need to remain close enough to the voters they claim to speak for. From a bottom-up perspective, they have to appear to be 'one of us' in contexts of (at least formal) egalitarianism between citizens. They thus have to constantly reconcile opposing imperatives of eminence and nearness.

The manifestations of material and symbolic resources lead to the formation of the political elite that is responsible for constructing an internal order based on the rule of law. Here is the connection with international institutions and law with local elites in charge of producing the legal order: Globalization, on the other hand, requires the replacement of numerous national laws and jurisdictions by uniform global standards in order to remove barriers to capital accumulation at the global level (CHIMNI, 2004, p.7).

According to Trubek (1972, p.5), one of the features of modern law is the purposiveness in the construction of social order. In this sense, social ordering by modern law:

$[\ldots]$ is conscious and rational; and since it has been consciously constructed, modern law must necessarily have some self-conscious purpose. But the core conception of purposiveness is broader than that implied by mere conscious design. Modern law is also viewed as an instrument through which a variety of possible social goals may be achieved. Thus, it not only releases man from the grasp of traditional norms and values, it also gives him the means to shape the world in which he lives. The core conception of legal purposiveness is, therefore, highly instrumental: It assumes that social life can be shaped by some social will, for example a modernizing elite, which brings about development through legal enactment and enforcement.

This is an important intersection between International and Domestic Law in the sense of the last capturing the features of the first in such manner that only political elite would have access to the means of controlling what is and how the precepts of International Law is incorporated 
and interpreted, thus, promoting the exclusion of much of the population. In the process of constructing the social order using the law guarantees that whatever is different from the so-called modernizing project is considered outdated, based on pointless traditions that impede the inevitable development as posed by international institutions (MORRISON, 2012). Trubek $(1972$, p.7) points out to the fact that law is:

[...] one form of technical discipline employed for legitimizing purposes. Identifying anything as a legal problem denies to a significant extent that it involves any political questions, since an issue is generally termed "legal" if there is some pre-existing norm or standard which will determine the controversy. Once political issues have been "legalized" in this fashion, they can be resolved only by the specialized elite who know the existing rules and the techniques of their application.

Now we turn our attention to the principle of prior consultation as one of the essential principles in International Environmental Law, which along with sustainable development provides the basis for mediating environment protection and social and economic development. Although two seemingly noble goals, what are embedded in enacting and enforcing such principles? What does it mean to people with no access to the technical knowledge of the law?

\subsection{The prior consultation principle - theoretical and empirical evi- dence of exclusion}

The landmark of International Environmental Law is the Declaration of the United Nations Conference on the Human Environment (Stockholm Declaration, 1972). ${ }^{11}$ As one might observe in Figure 1 - Word cloud of the Stockholm Declaration - the concept of prior consultation, or even its derivatives and connected ideas do not appear as the central concern of the countries or UN.

11 In http://www.un-documents.net/unchedec.htm. Last Access: April 3, 2018. 


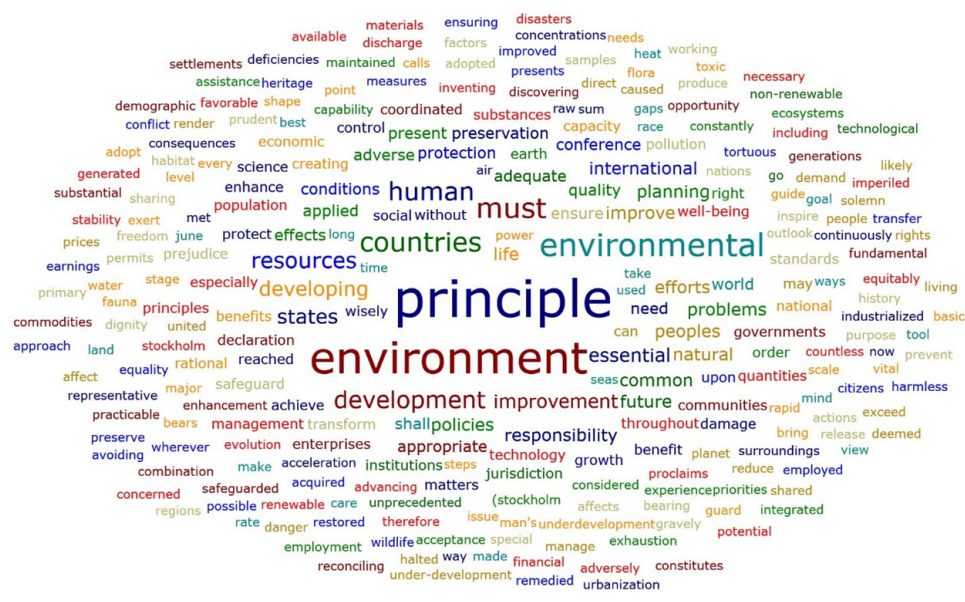

Figure 1 - Word cloud of the Stockholm Declaration made by the author using the software ATLAS.ti.

The principle as it is today has been incorporated into International Environmental Law only 20 years later in the Rio Declaration. Important to note that the prior consultation principle is a derivative of other fundamental principles in the International Environmental Law, especially the principle of public participation. As such, the public participation principle is outlined in Principle 10 of the Rio Declaration on Environment and Development (1992):

PRINCIPLE 10 Environmental issues are best handled with the participation of all concerned citizens, at the relevant level. At the national level, each individual shall have appropriate access to information concerning the environment that is held by public authorities, including information on hazardous materials and activities in their communities, and the opportunity to participate in decision-making processes. States shall facilitate and encourage public awareness and participation by making information widely available. Effective access to judicial and administrative proceedings, including redress and remedy, shall be provided. ${ }^{12}$

As we observe below in Figure 2, the prior consultation of the people experiencing any impact due to changes in the surrounding environment is connected directly to development.

12 In http://www.unesco.org/education/pdf/RIO_E.PDF. Last Access: April 3, 2018. 


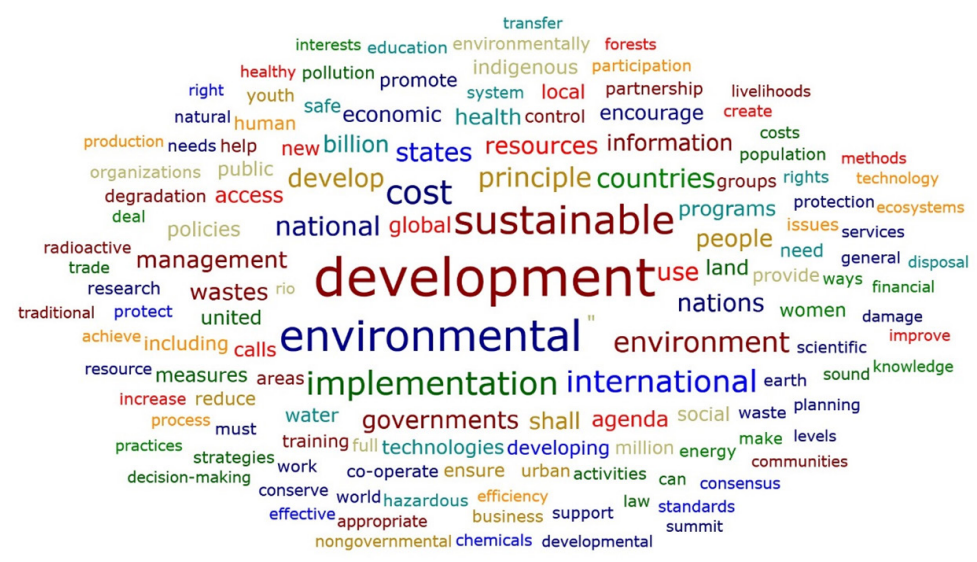

Figure 2 - Word cloud of the Rio Declaration made by the author using the software ATLAS.ti.

In this sense, the Rio Declaration states the all the principles are subject to the sustainable development principle, which according to Viriyo (2012, p. 1) [...] implies two main objectives, which are environmental protection and economic development. This concept has been stated in the Stockholm Declaration, Principle 8 in these terms: Economic and social development is essential for ensuring a favorable living and working environment for man and for creating conditions necessary for the improvement of the quality of life. However, nor the Declaration or the court cases that reached the International Court of Justice, mainly the Gabcikovo-Nagymaros Case, ${ }^{13}$ did not state the normative content of the obligation, thus, leaving opened the terms and conditions for the "sustainable development" to the North perception of development as observed in the Declaration's opening remarks: In the developing countries most of the environmental problems are caused by underdevelopment.

In order to operationalize the principle of prior consultation, so the countries might implement it in their legal orders, the United Nations Environment Programme (UNEP) developed the document called Guidelines for the Development of National Legislation on Access to Information, Public Participation and Access to Justice in Environmental Matters, which in the Guideline 8 reads: States should ensure opportunities

13 In http://www.icj-cij.org/files/case-related/92/092-19970925-JUD-01-00-EN.pdf. Last Access: April 3, 2018. 
for early and effective public participation in decision-making related to the environment. To that end, members of the public concerned 2 should be informed of their opportunities to participate at an early stage in the decision-making process. ${ }^{14}$

An essential dimension of the principle of prior consultation is related to the participation of the indigenous people, which in most of the cases is the group of people that suffer the most significant damages and lack appropriate involvement in the event of large projects. According to Article 7, 3 of the Convention concerning Indigenous and Tribal Peoples in Independent Countries (169) of the International Labour Organization:

\begin{abstract}
Governments shall ensure that, whenever appropriate, studies are carried out, in co-operation with the peoples concerned, to assess the social, spiritual, cultural and environmental impact on them of planned development activities. The results of these studies shall be considered as fundamental criteria for the implementation of these activities. ${ }^{15}$
\end{abstract}

The right to prior consultation is consistent with the rights of indigenous peoples to be heard and to participate, through their institutions and by their values, customs, forms of organization, decisions about undertakings and measures of any nature that affect or may affect their territories or their cultural life. The violation of such right might assume the form of consultation before and after the construction of projects disregarding the cultural aspects, and the absence of prior consultation at all (SCHILLING-VACAFLOR; FLEMMER, 2013).

At this point of the study, we need to move to a different level, meaning observing how local body of laws absorbed the principle of prior consultation and his derivative principles. In Brazil, the principle is connected to the obligation to perform the environmental impact assessment (EIA) for projects that might cause impacts to the environment before receiving he permission to install and operate. At the constitutional level the EIA is required under the article $225, \S 1$, IV in the following terms:

14 In http://wedocs.unep.org/handle/20.500.11822/11182. Last access: April 4, 2018.

15 In http://www.ilo.org/dyn/normlex/en/f?p=NORMLEXPUB:12100:0::NO::P12100_ILO_

CODE:C169. Last access: April 4, 2018. 
Article 225. All have the right to an ecologically balanced environment, which is an asset of common use and essential to a healthy quality of life, and both the Government and the community shall have the duty to defend and preserve it for present and future generations.

Paragraph 1. In order to ensure the effectiveness of this right, it is incumbent upon the Government to:

IV - demand, in the manner prescribed by law, for the installation of works and activities which may potentially cause significant degradation of the environment, a prior environmental impact study, which shall be made public; ${ }^{16}$

Within the scope of the EIA as a requirement for issuing the licensing for projects and activities potentially harmful for environment, the Resolution 1/86 issued by the National Council for the Environment (CONAMA) states that the state and the city authorities will establish the deadline for receiving comments and if necessary hold public hearings to present information about the project and potential impacts on local population. ${ }^{17}$

The EIA for the construction of the Belo Monte Dam is representative of the main argument of this study. The EIA for this project has been presented in a public hearing in the city of Altamira, Pará to the people that somehow would feel negative impacts by the project.

The Belo Monte project was raised by the first in the 1970's as the result of the II National Development Plan made by the government under the presidency of Ernesto Geisel. The project has received several critics across the 1980's, and 1990's from NGO's, academics, and indigenous people, which the main argument was the negative impacts the project would cause to the region; however, the objections never reached the media as it should have. In the 2000's the project started to receive attention due to the beginning of the EIA, and mainly due to several blackouts that happened in the country that lead to the Federal Government to enact the temporary act (Medida Provisoria) 2152/2001 that forced the CONAMA to create simplified forms of obtaining environmental licenses for the energy sector. Several judicial procedures were filed against the project, which after back and forth in 2009 the licensing procedure was resumed (ZUGMAN, 2013).

With no alternative, the public hearings were scheduled to

16 In http://english.tse.jus.br/arquivos/federal-constitution. Last access: April 4, 2018.

17 In http://www.mma.gov.br/port/conama/legiabre.cfm?codlegi=23. Last access: April 4, 2018. 
present the EIA in the cities of Altamira, Brasil Novo, Vitoria do Xingu, and Belem. In one of the hearings, professor Rodolfo Salm (PhD in Environmental Science by East Anglia University, and professor in the Pará Federal University), a member of the expert panel and part of the community interested in the project reported:

When I arrived at the audience, a crowd of demonstrators was already waving with banners and flags outside the gym, making it clear that their opposition to the play is alive and convinced of their position. But audience dynamics did not favor discussion...The first hours were dedicated to the presentation and defense of the project by local politicians, Eletronorte and Leme Engenharia, in a kind of multimedia event. And even entitled to an allegedly friendly host, "Ana Maria Braga style," walking with a headphone in front of projections of images of the dam project and other fantasies, such as beautifully urbanized neighborhoods superimposed on the current stilts of the city, is not foreseen anywhere in the project...Each registered person was entitled to three minutes for an oral question, three for the reply of the proposers, with right of reply and rejoinder. That is, who closed the session were always the entrepreneurs. Some questions were quite harsh, exposing the precariousness and high environmental risk of the project. As at the moment when the contamination of the wells was questioned, with the inevitable elevation of the water table. They answered that the nine wells studied by their team already had levels of contamination that made them inappropriate for water consumption... The appeal of the defenders of the dam again was not the argument, but the rhetoric and the disqualification of the opponent (now they call us developmental, sometimes uninformed). They thanked the question and regretted that he was wrong, since the ratio between the steady energy and the installed power of Belo Monte had been recalculated upwards. But he did not say how, nor for how much. For those who do not know, it is worth remembering that Professor Fearnside is one of the most respected scientists in the world in this area, with publications on the subject in the main international journals. And yet his remarks were dismissed by EIA advocates as mistaken for misinformation. Imagine then those of the ordinary citizen, unable to enter so deeply into these technicalities. And not only it, but several experts hit this key...So what? It is the water that drinks the most here. Since they are already contaminated, does it not hurt to increase this contamination a dozen or a hundred times? Altamira alone is not an open sewage like the neighborhoods on the outskirts of Belém because all the in natura residue is drained freely into the river at its normal level. Then, made the dam, we would probably live in a situation similar to those degrading districts that surround the capital of Pará. Reasoning such as "it is okay 
to contaminate your water because it is already unsuitable for use" is a synthesis of EIA (Environmental Impact Assessment) proponents' thinking. In fact, they say: "It is okay to destroy your city, because it was no longer adequate even to live."18 (translated by the Author)

The report calls attention to the functionalist and procedural feature of the prior consultation in the process of approving the project. It is possible to observe the tension between the developmental approach and the interests of the communities. The modus operandi used by the companies to comply with the prior consultation requirement, in this case, is representative of what's happening in Brazil, meaning, large projects are approved without providing full and honest information in the prior consultation hearings so that local communities might participate effectively in the process. The technical language used in the EIAs is virtually impossible for locals to understand all the possible implications of the project. The language of the need and prospects of local development by accepting the construction of the project is compelling, being captured by the local elite, which tends to push the agenda to the most vulnerable population in the community. This what Jean-Philippe (2004, p.227) refers to in analyzing large investments in West Africa:

In a context where the ability to deal with external sources of funding is concentrated in a small elite group, the bargaining strength of common people is inevitably limited, hence their ready acceptance of highly asymmetric patterns of distribution of programme benefits. If the intervention of the elite results in an improvement in the predicament of the poor, however small that improvement, the latter tend to be thankful to their leader(s): the new outcome represents a Pareto improvement over the previous situation and this is what matters after all.

The disqualification of the local population and traditional, and the use of the authoritative arguments are the most common technique used by institutions and elites to exclude local community active participation. This is precisely what Escobar (2011, p. 52-3) referred to:

At times, development grew to be so important for Third World countries that it became acceptable for their rulers to subject their populations to an infinite variety of interventions, to more encompassing forms of power and systems of control;

18 In https://www.ecodebate.com.br/2009/10/08/belo-monte-a-farsa-das-audiencias-publicas-artigo-de-rodolfo-salm/. Last access: April 4, 2018. 
so important that First and Third World elites accepted the price of massive impoverishment, of selling Third World resources to the most convenient bidder, of degrading their physical and human ecologies, of killing and torturing, of condemning their indigenous populations to near extinction; so important that many in the Third World began to think of themselves as inferior, underdeveloped, and ignorant and to doubt the value of their own culture, deciding instead to pledge allegiance to the banners of reason and progress; so important, finally, that the achievement of development clouded the awareness of the impossibility of fulfilling the promises that development seemed to be making.

In the article Community Driven Development, Collective Action and Elite Capture in Indonesia, Dasgupta; Beard (2007) propose a threefold approach to challenge the dominant development model and the elite capture of local community and vulnerable groups: (1) decentralization, which helps to design of contextually appropriate projects, target the beneficiaries, and provide accountability to local population; (2) democratization; and (3) collective action.

As observed in the case of Belo Monte, for a period the project was challenged severely by the local community, however, the imperatives of development were sufficient to move it forward despite the severe critics of the real need and efficiency vis-à-vis the damages to the environment and local communities. The Greenpeace sums up the inadequacy of the project and unveils the real motivation:

Speaking of blackout, a possibility that does not exist at the moment, and that the energy of Belo Monte will guarantee the comfort of the population in the South and Southeast of the country, which is a falsehood. Transmitting the energy generated in the North to other regions of the country is not only inefficient but would also require investments in transmission lines that will not be made at this time. The bulk of what Belo Monte generates will power electro-intensive industries such as mining and steel mills, which produce raw materials for export. In fact, we will be paying for the benefit of entrepreneurs and other countries that need our ores and steel to sustain their growth, such as China. ${ }^{19}$ (translated by the Author)

The prior consultation in the case of the Fundão Dam shows a more perverse side. In the article $O$ Caso do Rompimento da Barragem no Rio Doce, Caio Borges \& Tchenna Fernandes Maso present a compelling report:

19 In http://www.greenpeace.org/brasil/pt/Noticias/A-feia-historia-de-Belo-Monte/. Last access: April $10,2018$. 
The central dispute of the conflict involves the recognition of who is attained and, in his sense the company carried out compensation according to its own criteria, without any type advertising, regardless of the possibility, without any consultation or participation of the victims. In the case of socioeconomic registers that recognized families or not, they were completely abusive, requiring in some cases evidentiary burden mechanisms the elderly and the victims who could not rescue anything. ${ }^{20}$

\section{FINAL REMARKS}

The objective of this study is not to adopt a nihilist stance. As such, although its imperialistic feature as argued, the world is better with than without International Law. However, the critical approach provides the cautionary view in dealing with it.

The prior consultation principle, along with other tenets as born and developed over the years should be viewed under the perspective of the population affected by large projects, which in the Global South presents an additional challenge considering the local elites.

As such, the universal and rational ontologies of international law will defy the traditions and religions of many peoples, which often are pushed to the corner as the antique or against development and modernity. The mere presentation of plans and studies to these people does not satisfy the checkbox of prior information and consultation.]

Even providing comprehensive and understandable information and data, this might be not enough to meet the ultimate teleological view of the environment, meaning that sustainable development should include other factors that rational economic and social sciences do not include, such as religion and tradition.

\section{REFERENCES}

ANGHIE, A. Imperialismo y Derecho internacional. Bogotá: Siglo del Hombre, 2016.

ANGHIE, A. Finding the peripheries: sovereignty and colonialism in nineteenth-century international law. In: Imperialism, sovereignty and the making of international law. New York: Cambridge University Press, 2005. p. 32-114.

20 In http://sur.conectas.org/o-caso-rompimento-da-barragem-no-rio-doce/. Last access: April 10, 2018. 
BEDJAOUI, M. Pour un nouvel ordre economique international. Paris: Unesco, 1979.

BEST, H. et al. (Eds.). The Palgrave handbook of political elites: 2018 edition. London: Palgrave Macmillan, 2017.

BORGES, C.; MASO, T. F. O caso do rompimento da barragem no Rio Doce: o uso de estratégias internacionais como uma forma de reduzir as assimetrias de poder na relação entre direitos humanos e empresas. Revista Internacional de Direitos Humanos, v. 14, n. 25, p. 71-88, jul. 2017. Disponível em: $<$ https://sur.conectas.org/wp-content/uploads/2017/09/sur25-portugues-caio-borges-tchenna-fernandes-maso.pdf $>$. Acesso em: 11 abr. 2018.

CHIMNI, B. S. International institutions today: an imperial global state in the making. European Journal of International Law, v. 15, n. 1, p. 1-37, 1 fev. 2004.

DASGUPTA, A.; BEARD, V. A. Community driven development, collective action and elite capture in Indonesia. Development and Change, v. 38, n. 2, p. 229-249, 25 abr. 2007.

ESCOBAR, A. Encountering development: the making and unmaking of the Third World. Princeton: Princeton University Press, 2011.

GRUBER, L. Ruling the world. Princeton: Princeton University Press, 2000 .

HOLLANDA, C. B. DE. Teoria das elites. Rio de Janeiro: Zahar, 2011.

LYOTARD, J.-F. La condicion postmoderna. 8. ed. Madrid: Catedra, 2004.

MEARSHEIMER, J. J. The tragedy of great power politics. New York: W. W. Norton \& Company, 2014.

MORRISON, W. Filosofia do direito: dos gregos ao pós-modernismo. 2. ed. São Paulo: WMF Martins Fontes, 2012.

MUTUA, M.; ANGHIE, A. What Is TWAIL? Proceedings of the Annual Meeting (American Society of International Law), v. 94, p. 31-40, 2000.

OKAFOR, O. C. Critical Third World Approaches to International Law (TWAIL): theory, methodology, or both? International Community Law Review, v. 10, n. 4, p. 371-378, 1 dez. 2008.

PLATTEAU, J.-P. Monitoring elite capture in community-driven development. Development and Change, v. 35, n. 2, p. 223-246, 13 abr. 2004. 
PUTNAM, R. D. The comparative study of political elites. Englewood Cliffs: Prentice Hall, 1976.

REIS, E. P.; MOORE, M. Elite perceptions of poverty and inequality. Cape Town; London; New York: Zed, 2005.

SCHILLING-VACAFLOR, A.; FLEMMER, R. Why is prior consultation not yet an effective tool for conflict resolution? The case of Peru. [s.1.] GIGA Working Papers, 2013. Disponível em: <https://www.econstor.eu/ handle/10419/72462>. Acesso em: 11 abr. 2018.

TRUBEK, D. Toward a social theory of law: an essay on the study of law and development. Faculty Scholarship Series, 1 jan. 1972.

VIRIYO, A. Principle of sustainable development in international environmental law. Rochester: Social Science Research Network, 22 ago. 2012. Disponível em: <https://papers.ssrn.com/abstract=2133771>. Acesso em: 10 abr. 2018.

ZUGMAN, D. L. O dever de consulta aos povos indígenas e a construção da usina de Belo Monte. Revista Discente DIREITO GV - redGV, v. 1, n. 3, p. 94-106, 1 jul. 2013. Disponível em: $<$ https://direitosp.fgv.br/sites/ direitosp.fgv.br/files/artigo-Edicao-revista/redgv_3ed_artigo_6_-_o_ dever_de_consulta_aos_povos_indigenas_e_a_construcao_da_usina_de belo_monte.pdf>. Acesso em: 11 abr. 2018.

Artigo recebido em: 08/10/2018.

Artigo aceito em: 14/04/2019.

\section{Como citar este artigo (ABNT):}

CASTRO, D. The resurgence of old forms in the exploitation of natural resources: the colonial ontology of the prior consultation principle. Veredas do Direito, Belo Horizonte, v. 16, n. 34, p. 343-365, jan./abr. 2019. Disponível em: <http://www.domhelder.edu.br/revista/index.php/veredas/ article/view/1387>. Acesso em: dia mês. ano. 